\title{
Review
}

\section{ACO (Asthma-COPD Overlap) Is Independent from COPD: The Case Against}

\author{
Peter M. A. Calverley ${ }^{1}$ and Paul Phillip Walker ${ }^{2,3, *}$ \\ 1 Department of Clinical Science, University of Liverpool, Liverpool L9 7AL, UK; pmacal@liverpool.ac.uk \\ 2 Liverpool University Hospitals Foundation NHS, University of Liverpool, Liverpool L9 7AL, UK \\ 3 Department of Respiratory Medicine, Aintree Hospital, Lower Lane, Liverpool L9 7AL, UK \\ * Correspondence: ppwalker@liverpool.ac.uk
}

check for

updates

Citation: Calverley, P.M.A.; Walker, P.P. ACO (Asthma-COPD Overlap) Is Independent from COPD: The Case Against. Diagnostics 2021, 11, 1189. https://doi.org/10.3390/

diagnostics11071189

Academic Editor: Koichi Nishimura

Received: 14 May 2021

Accepted: 21 June 2021

Published: 30 June 2021

Publisher's Note: MDPI stays neutral with regard to jurisdictional claims in published maps and institutional affiliations.

Copyright: (c) 2021 by the authors. Licensee MDPI, Basel, Switzerland. This article is an open access article distributed under the terms and conditions of the Creative Commons Attribution (CC BY) license (https:/ / creativecommons.org/licenses/by/ $4.0 /)$.

\begin{abstract}
Over the last decade interest has been shown in people with symptomatic lung disease who have features both of COPD and asthma. In this review we examine how COPD and asthma are defined and examine clinical characteristics of people defined by researchers as having asthmaCOPD overlap (ACO). We look at pathological and physiological features along with symptoms and consider the impact of each diagnosis upon therapeutic management. We highlight challenges in the diagnosis and management of airway disease and the various phenotypes that could be part of $\mathrm{ACO}$, in so doing suggesting ways for the clinician to manage patients with features of both asthma and COPD.
\end{abstract}

Keywords: COPD; asthma; asthma-COPD overlap; respiratory pathophysiology; bronchodilator reversibility

\section{Introduction}

Chronic obstructive pulmonary disease (COPD) is now recognised to be a major cause of ill health, increased health care expenditure and premature mortality internationally [1]. The current definition of COPD advocated by the Global initiative for Obstructive Lung Disease (GOLD) highlights the importance of persistent airflow obstruction as a defining characteristic of this condition [2]. Clinically this presents a simple decision. Airflow obstruction is either present or it is not when the patient performs a technically satisfactory spirogram. However, the underlying biology of this apparently simple proposition is more complex.

Longitudinal studies measuring lung function prospectively and cross sectionally over time [3-5] have shown that both the $\mathrm{FEV}_{1}$ and FVC decrease with age and this is accelerated when people smoke tobacco or are exposed to other noxious inhaled insults [4-6]. Moreover, it is now clear that early life events impact significantly on lung growth and subsequent decline, resulting in a range of trajectories which the patient may follow up to the point where a diagnosis of COPD is confirmed by spirometry [7]. Traditionally, airflow obstruction is defined by the ratio of the $\mathrm{FEV}_{1}$ to $\mathrm{FVC}$ with a value of 0.7 or less signifying that obstructed airflow is present. This simple measurement identifies the presence of emphysema on CT scanning [8] and people at risk of accelerated lung function loss, at least in the earlier stages of COPD [9]. However, this ratio decreases with age and apparently healthy elderly people can be classified as having COPD based on this measurement [10]. This has led physiologists to propose that the lower limit of normal should be used to identify people where the ratio is below that expected by age [11]. This classifies people rather differently with more young people and fewer elderly ones being considered to have airflow obstruction. In practice, this changes relatively little at least in terms of the results of clinical trials [12] and there are now data suggesting that the fixed ratio of $\mathrm{FEV}_{1} / \mathrm{FVC}$ of 0.7 is the best predictor of subsequent ill health [13]. 
If it has proven difficult to define airflow obstruction, it has been even harder to decide what the term 'persistent' means. This term could imply that obstruction did not resolve when measured over time, but whether this could include significant improvements in lung function that were still below the normal predicted value, as is seen in some patients with chronic asthma, was not clear. These differences in interpretation were soon recognised as having therapeutic significance. In the 1990s an important paper from the Netherlands suggested that inhaled corticosteroids (ICS) could produce significant improvements in symptoms and lung function in COPD patients [14]. Subsequently these data were challenged, especially by physicians in the UK, who argued that the improvements seen were due to the inclusion of patients who would normally be diagnosed as having bronchial asthma. This led to an intense debate about how to best define bronchodilator reversibility in order to separate COPD from asthma. In Europe, a very tight definition of irreversible disease was proposed which precluded almost any lung function change after exposure to an inhaled bronchodilator [15]. This created a 'Catch 22' situation where any patient where lung function improved with treatment could not have COPD because treatment had improved their lung function! Such a tight definition is not used today but illustrates evolution over time.

As a result, rather than consider in more detail what bronchodilator reversibility might signify in a patient with structural lung damage due to cigarette (or any other relevant) exposure, the tendency has been to assign patients to mutually exclusive silos-either COPD or asthma. Clinicians have always realised that this is an oversimplification and that some typical COPD patients would show larger than expected benefit from treatment of various types. What has been less clear is whether this behaviour represents a variation within an established diagnosis or is a discrete condition which consistently behaves differently from 'true' asthma or COPD.

Over the last decade there has been renewed interest in the idea of an asthma-COPD overlap (ACO) state in part driven by the desire of the pharmaceutical industry to identify a subset of COPD patients who might respond better to the existing anti-inflammatory treatments and to explain why some asthmatic patients did not improve to the degree anticipated when given them. The most cogent rational academic exploration of this idea came from Gibson et al. in 2009 [16]. Subsequently there have been many publications reporting data in patients believed to be exhibiting ACO and suggestions have been made about how best to operationalise this concept [17-19]. In this review we will consider what has been proposed and outline our reasons for believing that ACO is not a helpful way to understand the variation seen in the way that disease develops in patients with asthma or COPD.

\section{Defining ACO}

A key issue limiting the usefulness of the ACO concept is the lack of a consistent definition. This not only hinders academic study but also confuses the clinician. This problem is not restricted to ACO but has bedeviled the field of 'airways disease' for the last 60 years. Indeed, the portmanteau term 'airways disease' to describe asthma, COPD and related conditions is itself unsatisfactory as it fails to account for airflow obstruction due to emphysema. Clearly if we have issues defining asthma and COPD, it is going to be hard to identify overlaps between them.

As has been noted before, defining both asthma and COPD is like love-everyone knows what it is when it happens, but it is hard to explain to other people. By the 1980s advances in pulmonary pathology and physiology meant that definitions based only on symptoms such as chronic bronchitis were superseded by approaches using structural and/or lung function criteria. The CIBA symposium in 1959, perhaps the most famous of the meetings which attempted to re-define these conditions, proposed definitions based on variability in lung function for asthma, the presence of enlarged airspaces due to tissue loss for emphysema and symptoms of chronic cough [20]. Helpful as these definitions were in providing a focus for further study, they contained a fundamental weakness, namely 
that each relied on a different domain — physiology, pathology or symptomatology-to characterise the disease, building in the study of overlap states from the outset.

In the 1970s and 1980s, attention was paid to whether chronic bronchitis or physiology, in the form of the $\mathrm{FEV}_{1}$, identified discrete natural histories of disease and whether this differed from that seen with patients diagnosed in life with emphysema. The famous longitudinal study of British postal workers led by Charles Fletcher provided the unexpected answer that it was lung function that identified individuals whose lung disease progressed with smoking, rather than the symptoms of bronchitis [21]. Thereafter symptoms were seen to be secondary to lung pathology identified by abnormal lung function rather than identifying a discrete condition. While this is likely to be true, the importance of symptoms like mucous hypersecretion as a marker for respiratory infection and exacerbation [22] and lung disease in the earliest phases of COPD [23] has been neglected until relatively recently.

The overlap between emphysema and bronchitis (clinically defined) seemed to have an international dimension with workers in the USA reporting most of their patients with chronic airflow obstruction as having emphysema (based on CXR appearances) while in Britain similar patients were defined as being bronchitic [24]. Eventually these semantic problems were resolved, but there was still a belief that patients with emphysema without bronchitis maintained normal arterial blood gas tensions while those reporting bronchitis were more likely be hypoxaemic [25]. Again, subsequent pathology studies showed that emphysema could be associated with hypoxaemia [26]. With hindsight it is likely that some of the 'blue and bloated' patients had undetected bronchiectasis and/or left ventricular dysfunction, but this illustrates the way in which ideas about airflow obstructive disorders has been refracted through the tools available for their study rather than any intellectual limitation of those leading the investigations.

The contrast between asthma and bronchitis was not immune from the debate between 'lumpers and splitters'. Unlike the British who felt that chronic bronchitis was a discrete disorder of prognostic significance, the Dutch group in Groningen led by Dick Orie advocated the concept of chronic non-specific lung disease which recognised the heterogeneous nature of conditions others would describe as bronchitis, emphysema or asthma, and grouped them together [27]. In this approach we have the origin of the concept we now consider as ACO and, as noted already, it received considerable push back when the results of their clinical trial of inhaled corticosteroids was first published [14]. However, the conceptual framework developed in the Netherlands was taken up by Gordon Snider in Boston and led to his visual representation of COPD in a non-proportional Venn diagram which was adopted by the American Thoracic Society in its original Standards of Care for COPD document [28]. Thus, a potential for ACO was recognized, but its nature was not clarified.

Longitudinal studies in the Netherlands and New Zealand in young people who have the clinical and physiological characteristics of asthma have shown how over time they can develop fixed airflow obstruction which is often diagnosed as being COPD [29,30]. Whether these people have the same pattern of structural damage seen in typical smoking induced COPD is unclear as is their response to therapy. By contrast, much less information is available about whether people with typical COPD go on to develop disease features more typical of chronic asthma.

Although interest in this topic subsequently declined, the 2009 article by Gibson et al. reignited old uncertainties about whether a discrete phenotype of patients with features of both asthma and COPD existed [16]. These authors approached this from an asthmatic perspective and placed significant emphasis on the role of the bronchodilator response in identifying these patients, as well as emphasising the increased sputum neutrophilia seen in their ACO subjects compared with asthmatics and healthy older adults. Coming at a time of concerns about the risk of pneumonia developing in COPD patients treated with ICS, this approach offered a way of identifying a subgroup for which the benefit of ICS treatment was easier to justify. 
In response to these concerns, the Global Initiative in Asthma (GINA) and Global Initiative in Obstructive Lung Disease (GOLD) produced a joint consensus document highlighting practical approaches to the management of ACO [31]. Subsequently the report of workshops convened by the ATS and ERS were published [19,32]. The GOLD/GINA approach was not to offer a specific set of criteria on which a diagnosis of ACO was based but to suggest that ACO could be considered when features usually considered typical of asthma or COPD were present in the same patient [31]. This group offered a series of choices to the clinician about clinical and laboratory features they felt were important, and more detail can be found on the respective websites. There was no attempt to weight the features for their relative importance, a task sensibly left to the individual clinician to decide, from what is basically advice on what to consider in managing patients presenting with atypical clinical findings. However, this level of individual decision makes it hard to draw conclusions about the nature and management of this condition and assumes that treatment approaches valid for the individual diseases are as effective in someone exhibiting these 'overlap' findings.

By contrast, the ATS workshop considered a wider range of issues and raised a series of research questions which needed to be addressed before the nature of ACO could be considered finalised [32]. The European consensus group reviewed the entry criteria used in a range of clinical trials of asthma and COPD and developed a series of major and minor diagnostic criteria summarised in Table 1. This group provided the clearest operational definition of ACO but, to date, this has not been widely accepted, with other groups adapting it to local perceptions of what the key features of ACO might be. The resulting plethora of reported definitions is summarised in the helpful review of Cazzola and Rogliani [33]. It is no surprise in this setting that the type of patients included in what are mainly observational studies appear to be rather different in their nature, illustrated by Barczyk et al. [34].

Table 1. A Consensus Definition of ACO proposed from an ERS Sponsored Round-table Discussion [19]. Diagnosis requires the presence of all 3 major criteria plus 1 minor criteria. LLN = lower limit of normal, BDR = bronchodilator reversibility.

\begin{tabular}{lll}
\hline \multicolumn{1}{c}{ Major Criteria } & \multicolumn{1}{c}{ Minor Criteria } \\
\hline - $\quad \begin{array}{l}\text { Persistent airflow limitation } \\
\text { (post-bronchodilator FEV1/FVC }<0.70 \text { or } \\
\text { LLN) in individuals } 40 \text { years of age or } \\
\text { older; LLN is preferred }\end{array}$ & $\begin{array}{l}\text { Documented history of atopy or allergic } \\
\text { At least } 10 \text { pack-years of tobacco smoking } \\
\text { or equivalent indoor or outdoor air } \\
\text { pollution exposure (e.g., biomass) } \\
\text { Documented history of asthma before } 40 \\
\text { years of age or BDR of }>400 \mathrm{~mL} \text { in FEV1 }\end{array}$ \\
\end{tabular}

These problems in definition raise several concerns about the utility of the term ACO as an aid to both academic and clinical understanding of people with objectively defined airflow obstruction. In the following sections we will examine what evidence we have for a discrete overlap of pulmonary pathology between asthma and COPD, whether patients meeting the definition of ACO behave differently from others not diagnosed in this way and whether objective physiological tests which are often the main driver of an ACO diagnosis can be relied on to distinguish these patients from others with chronic airflow obstruction.

\section{A Pathology of ACO?}

There is a dearth of evidence for a discrete pathology occurring in ACO patients. This reflects the lack of a clear definition discussed above and the fragmented nature of the data about structural and immunological features of those who do meet whatever definition is considered appropriate. The issue is not just whether the pathologies typical of asthma 
or COPD co-exist in the same person, but in how many people such features are present without them exhibiting the defining conditions of the overlap state.

In most cases it is accepted that a prior clinical diagnosis of asthma indicates the continuing presence of that condition. However, this is not necessarily the case. Often the diagnosis is not confirmed by any objective measurement and, in the case of the overlap between asthma and obesity, an asthma diagnosis is often made in patients without any evidence of enhanced airway responsiveness or spontaneous fluctuation in lung function [35]. The clearest evidence for a common set of pathological characteristics in asthmatics has come from biopsy studies largely conducted in milder disease and autopsy data in the relatively few people who die from the disease. In most cases there are features of Th-2 inflammatory changes, increased numbers of eosinophils in the tissue and airway lumen and, as the disease worsens more neutrophils accumulate. A striking finding is the increase in bulk of the airway smooth muscle which helps explain several of the physiological features of the disease [36-38].

For many years there was a consensus based on chest X-ray studies that emphysema only rarely occurs in asthmatic patients but was a frequent finding in those presenting with COPD. It is now clear that in most COPD patients the loss of the small airways precedes the development of emphysema which becomes a more prominent feature as lung function loss worsens [39,40]. The advent of quantitative CT scanning has allowed the relationship between structure and function to be explored in life. One of the best studies is that of Hartley et al. who studied 171 asthmatics, 81 COPD patients and 49 healthy subjects [41]. Patients met standardised diagnostic criteria and were not classified as being $\mathrm{ACO}$ or non-ACO in nature. These workers found that airway wall thickness increased as $\mathrm{FEV}_{1}$ decreased in asthmatics, but the degree of air trapping, a measure of pulmonary hyperinflation, was the main driver of a low $\mathrm{FEV}_{1}$ in COPD patients. The degree of emphysema contributed to the decreased $\mathrm{FEV}_{1}$ in COPD patients but was infrequent in patients with asthma. Thus, different pathological changes contribute to the impaired physiology, but airways disease plays a role either directly or indirectly in both asthma and COPD.

These pathological issues have been more directly addressed by a Japanese group who report 3D CT imaging in COPD patients with and without a diagnosis of ACO based on the presence of a bronchodilator response and matched for their smoking history [42]. In this study an $\mathrm{FEV}_{1}$ change of more than $12 \%$ baseline and $200 \mathrm{~mL}$ after an unspecified bronchodilator or 4 weeks of anti-inflammatory treatment together with variable symptoms were used to define ACO. Patients exhibiting a positive response had thicker proximal airways and less evidence of emphysema than those who did not. However, the mean $\mathrm{FEV}_{1}$ in this study was relatively high at $70 \%$ predicted, so extrapolation to more severe COPD should be done with caution.

Direct study of the nature of airway inflammation in ACO subjects should help resolve matters. One of the few studies to report data on this topic came from a group in Basel who systematically collected biopsies from 129 COPD patients without features of asthma, 19 smoking asthmatics and 18 COPD patients with ACO, all of whom were undergoing diagnostic bronchoscopy and biopsy procedures. They defined ACO using a modified ERS consensus definition [43], but unlike other studies the ACO group did not show greater reversibility to salbutamol that the non-ACO COPD patients. The ACO patients had higher exhaled breath nitric oxide concentrations, more blood eosinophils and significantly better lung function than the COPD control group. These differences in disease severity make it difficult to interpret the greater degree of basement membrane thickening seen in the ACO patients compared with the smoking asthmatics. As the authors comment, their data is preliminary and other focused studies will be needed to address the question of what kind of pathological changes occur in what patients.

An alternative approach to establishing overlap would be to look for differences in biomarkers of tissue inflammation between ACO and non-ACO COPD patients. This would be a very helpful strategy if the biomarkers concerned were both specific and 
sensitive in distinguishing asthma from COPD. Many inflammatory biomarkers have been linked to asthma with fractional exhaled breath nitric oxide (FeNO), being widely used as a marker of Th-2 inflammation. Unfortunately, the inflammatory process and its attendant biomarkers change as the clinical presentation of asthma evolves, with a more neutrophilic, less eosinophilic profile being seen in severe asthma, especially among patients who are relatively resistant to systemic corticosteroid treatment [44]. Blood eosinophilia is seen as a marker of airway eosinophilia, although studies where these variables have been directly compared suggest that this relationship is relatively weak [45] and there is little agreement about what constitutes eosinophilia and how best to express the data. Unsurprisingly, a raised peripheral blood eosinophil count is not required in the diagnosis of asthma [46]. Nonetheless, the peripheral blood eosinophil count does predict the response to biological treatments in severe asthma [47] and in general population samples of COPD sufferers, those with an eosinophil count as high as 350-600 cells / $\mu \mathrm{L}$ have an increased risk of hospitalisation [48].

Attempts to use these variables to separate ACO from COPD patients who do not meet the clinical criteria for this condition have generated conflicting results. Li et al. found that in 48 patients (42\% with a history of smoking and 50\% taking ICS) that an FeNO $>31.5 \mathrm{ppb}$ identified patients with ACO who smoked with a sensitivity of $70 \%$ and a specificity of $90 \%$ [49]. However, both the reproducibility of these threshold values and their predictive power need to be replicated in other cohorts. Nonetheless, there is a growing sense that patients who have a history of asthma before the age of 40 behave differently to those whose smoking related COPD develops later in life. Data from Spain suggests that the airway responsiveness is greater, peripheral blood eosinophil count is higher and serum IgE levels are higher in COPD patients with a prior diagnosis of asthma [50]. Further work on well characterised cohorts preferably with appropriate CT imaging should help clarify these relationships. However, the largest comparative cohort study to date, NOVELTY, found no difference in blood eosinophil counts between the asthma, COPD and asthma-COPD overlap groups that they recruited [51], suggesting that blood eosinophils are not useful discriminants in routine clinical practice in identifying what physicians felt constituted ACO.

In many ways the most powerful argument for the existence of an overlap state between asthma and COPD comes from genetics. By combining data from several pathological studies in asthma and COPD, Christenson et al. found that genes associated with a Th2 phenotype in asthmatics were also expressed in patients with COPD and that blood eosinophil counts and airway responsiveness were increased when this was the case [51]. They argue that these genes might be involved in the earlier stages of the development of COPD. However, it is important to recognise that the pathological changes associated with COPD differed from those seen with asthma, with the exception of the eosinophil numbers. Clearly these findings also merit replication in patients meeting any of the current ACO definitions.

\section{The Clinical Significance of ACO}

It could be argued that it is not important whether or not there is a clear definition of ACO if clinicians can identify a group of patients who should be managed differently. This approach runs the risk of committing the Procrustean crime of making the facts fit the prejudice of the observer-in this case that ACO must exist.

In Table 2 [52-61] we summarise some of the many studies which have looked at the clinical characteristics of ACO (defined in a variety of ways) in clinical populations which vary by country and care setting. The reported prevalence of the condition varies as does the sample size studied, ranging from $1.5 \%$ to $27.4 \%$ of populations with asthma or COPD. As noted by Spanish workers, the very strict definition of substantial bronchodilator reversibility change excludes so many patients that the definition had to be relaxed to allow them to identify anyone with ACO [54]. This approach feels like a very uncertain way of defining a disease as the higher threshold had originally been suggested as a way 
of avoiding random variation in a positive BDR (see below). There is an impression that patients identified as having ACO are somewhat younger, are more symptomatic and more likely to report exacerbations than COPD patients not identified in this way. This is supported by several of the review articles which have summarised the findings in these and/or other data sets [16-18,33,62]. Two further studies are worthy of note. In a validation of the ERS symptom score, Nelsen et al. found that most of the symptoms in the battery worked as well for COPD as for ACO, i.e., clinically the patients were very similar. However, wheeze seemed to differ and was not a reproducible symptom, suggesting that reliance on this complaint, at least in COPD patients, could be misleading [63]. A different approach was used by Pascoe who reported a mathematical analysis of a health symptom questionnaire in a large population of patients with obstructive lung disease. The resulting model was accurate in distinguishing asthma and COPD but the authors suggest that patients not falling into these groups are very heterogeneous and hard to classify [64]. This heterogeneity is emphasised by the results of the NOVELTY study [52]. Here over 11,000 patients entered an observational study based on their doctor diagnosed asthma, COPD or ACO. There was substantial heterogeneity across the diagnostic groups and physician determined disease severity classes showing that, in the 'real world' diagnostic groupings are not rigidly applied.

Table 2. Selected studies reporting clinical features of people with ACO.

\begin{tabular}{|c|c|c|}
\hline Study & Definition of ACO & Main Findings \\
\hline Reddel et al. [52] & Physician diagnosis of asthma, COPD or both & $\begin{array}{c}12.4 \% \text { asthma and COPD (ACO) } \\
\text { More likely to smoke, higher blood neutrophil } \\
\text { count, more breathless and poorer health status } \\
\text { compared with asthma } \\
\text { Earlier diagnosis, more upper airway disease } \\
\text { compared with COPD } \\
\text { Bronchodilator responsiveness and FeNO } \\
\text { similar across groups }\end{array}$ \\
\hline Morgan et al. [53] & $\begin{array}{l}\text { Features of both: } \\
\text { COPD—post-bd FEV1/FVC below LLN and } \\
\text { Asthma—self report physician asthma diagnosis, use } \\
\text { of asthma medication last year or wheezing last year }\end{array}$ & $\begin{array}{l}\text { Prevalence of ACO } 3.8 \% \text { in LMIC residents } \\
\text { People with ACO had more biomass fuel } \\
\text { exposure, higher smoking and lower } \\
\text { educational attainment } \\
\text { Worse AFO than asthma or COPD groups }\end{array}$ \\
\hline Toledo-Pons et al. [54] & $\begin{array}{c}\text { Three groups: } \\
\text { Diagnosed with asthma and COPD } \\
\text { (smoking asthmatic) } \\
\text { COPD and bronchial hyperresponsiveness (FEV1 } \\
\text { increase }>400 \mathrm{~mL} \text { and } 15 \% \text { ) }(\text { COPD high } \\
\text { bronchial response) } \\
\text { COPD and eosinophilia (eosinophils }>300 \text { cells } / \mu \mathrm{L}) \\
\text { (COPD eosinophilia) }\end{array}$ & $\begin{array}{c}27.4 \% \text { fulfilled one or more criteria for ACO } \\
13.8 \% \text { smoking asthmatic, } 12.1 \% \text { COPD with } \\
\text { eosinophilia and } 1.5 \% \text { COPD with high } \\
\text { bronchodilator response } \\
\text { Smoking asthmatics were younger, more likely } \\
\text { female and more atopic }\end{array}$ \\
\hline Singh A et al. [55] & $\begin{array}{c}\text { COPD—post-bronchodilator FEV1 } / \mathrm{FVC}<0.7 \\
\text { Asthma— } 200 \mathrm{~mL} \text { and }>12 \% \text { improvement in FEV1 } \\
\text { with bronchodilator } \\
\text { ACO—both present }\end{array}$ & $\begin{array}{l}\text { Prevalence of ACO } 4.6 \% \text { in firefighters } \\
\text { Eosinophil count }>300 \text { cells } / \mu \mathrm{L} \text { more common } \\
\text { in ACO } \\
\text { More likely to have accelerated decline in FEV1 }\end{array}$ \\
\hline Cosentino et al. [56] & $\begin{array}{c}\text { ACO; either: } \\
\text { history of asthma or hay fever, FEV1/FVC }<0.7 \text {, } \\
>200 \mathrm{~mL} \text { and }>12 \% \text { improvement in FEV1 with } \\
\text { bronchodilator and less than } 15 \% \text { emphysema } \\
\text { on CT, or } \\
\text { FEV1/FVC }<0.7,>400 \mathrm{~mL} \text { and }>15 \% \text { improvement in } \\
\text { FEV1 with bronchodilator and less than } 15 \% \\
\text { emphysema on CT and less than } 15 \% \text { emphysema on } \\
\text { CT regardless of history of asthma or hay fever }\end{array}$ & $\begin{array}{l}\text { Compared to subjects with COPD and } \\
\text { emphysema ACO subjects were younger, more } \\
\text { likely African-American, higher BMI and more } \\
\text { likely to still smoke }\end{array}$ \\
\hline
\end{tabular}


Table 2. Cont.

\begin{tabular}{|c|c|c|}
\hline Study & Definition of ACO & Main Findings \\
\hline Krishnan et al. [57] & $\begin{array}{l}\text { ACO defined as }>40 \text { years old, current or former } \\
\text { smoker, FEV1/FVC }<0.7 \text { and }>200 \mathrm{~mL} \text { and }>12 \% \\
\text { improvement in FEV1 with bronchodilator }\end{array}$ & $\begin{array}{c}\text { Prevalence of ACO of } 18.2 \% \\
\text { More common in people diagnosed with both } \\
\text { asthma and COPD } \\
\text { Younger and higher BMI compared with } \\
\text { COPD cohort } \\
\text { More likely to smoke and less rhinitis than } \\
\text { asthma cohort }\end{array}$ \\
\hline Izbicki et al. [58] & $\begin{array}{c}\text { COPD was defined as FEV } 1<80 \% \text { predicted and } \\
\text { FEV1/FVC }<0.7 \text {. ACO was defined as this plus } \\
>200 \mathrm{~mL} \text { and }>12 \% \text { improvement in FEV1 with } \\
\text { bronchodilator }\end{array}$ & $\begin{array}{c}\text { No differences seen compared with the COPD } \\
\text { cohort except lower pre-bronchodilator lung } \\
\text { function in ACO }\end{array}$ \\
\hline $\begin{array}{l}\text { Barrecheguren et al. } \\
\qquad \text { [59] }\end{array}$ & $\begin{array}{l}\text { ACO defined as COPD patients reporting a previous } \\
\text { diagnosis of asthma } \\
\text { Classified as ACO2 if had } 2 \text { major or } 1 \text { major } \& 2 \\
\text { minor criteria: } \\
\text { Major criteria were improvement in FEV1 }>400 \mathrm{~mL} \\
\text { and }>15 \% \text { with bronchodilator, sputum eosinophilia or } \\
\text { a previous diagnosis of asthma before the age of } \\
\quad 40 \text { years } \\
\text { Minor criteria were increased total serum } \\
\text { immunoglobulin E, previous history of atopy or FEV1 } \\
>200 \mathrm{~mL} \text { and }>12 \% \text { on two or more occasions }\end{array}$ & $\begin{array}{c}\text { Prevalence of ACO of } 15.9 \% \\
\text { Two thirds did not fulfil ACO2 criteria } \\
\text { ACO subjects were more likely to be female, } \\
\text { had more exacerbations, had better lung } \\
\text { function and higher blood eosinophilia }\end{array}$ \\
\hline Llanos et al. [60] & $\begin{array}{c}40 \text { years old or greater with at least } 1 \text { asthma and } 1 \\
\text { COPD characteristic: } \\
\text { Asthma characteristic-even given a physician } \\
\text { diagnosis of asthma or had an 'asthma attack' in the } \\
\text { previous year } \\
\text { COPD characteristic-post-bd FEV1/FVC }<0.7 \text { and } \\
\text { ever told they had emphysema or chronic bronchitis } \\
\text { by a physician }\end{array}$ & $\begin{array}{c}\text { ACO subjects had poorer lung function than } \\
\text { those with asthma or COPD, higher eosinophil } \\
\text { counts than those with asthma or COPD and } \\
\text { had more 'asthma attacks' than the } \\
\text { asthma group }\end{array}$ \\
\hline Baarnes et al. [61] & $\begin{array}{l}\text { At least } 1 \text { previous hospitalisation for asthma and } 1 \\
\text { for COPD }\end{array}$ & $\begin{array}{l}\text { Subjects with ACO were older, more likely to } \\
\text { smoke, had lower educational attainment and } \\
\text { took less regular exercise }\end{array}$ \\
\hline
\end{tabular}

So far, data have largely focused on the overlap of COPD and asthma, i.e., in patients who look like they have COPD, how many have some features that are atypical and would fit better with a diagnosis of asthma. There are plentiful data about what happens when a young person diagnosed with asthma continues with symptoms into adulthood. Work from the Netherlands, Aberdeen, Australia and New Zealand have shown in patients followed for up to 45 years that a significant number of asthmatics go on to develop fixed airflow obstruction which is re-defined as COPD by the clinicians managing them [29,30,65-67]. In a recent report of children followed to age 45, a diagnosis of ACO based on the presence of airflow obstruction and a history of previous asthma irrespective of smoking history was made in an estimated 3\% of the population and, like COPD without an asthma diagnosis, was especially likely to do so in those with the worst lung function at the age of 7 years [65]. These data provide further support for the early origins of COPD in a significant number of patients but ACO described here represents a different entity from the COPD with asthmatic features that has fueled much of the ACO debate [68]. It is now clear that tobacco smoking decreases the effectiveness of inhaled corticosteroid treatment in both asthma [69] and COPD [70], further complicating the distinction between COPD with asthmatic features and asthma with features of COPD in longitudinal studies like that of Bui et al. [65]. 


\section{The Physiology of ACO}

Thus far, physiological measurements made in ACO patients have been largely confined to spirometry rather than collecting data about lung volumes or gas transfer. Some studies have reported the results of non-specific bronchial challenge testing with either inhaled histamine or methacholine as the inhaled agonist [71,72], but most studies restrict themselves to reporting the results of a single bronchodilator reversibility test (BDR) usually using inhaled salbutamol as the test drug. The interpretation of this apparently simple test has proven to be fraught with difficulty, especially in patients with COPD and has been reviewed in detail on several occasions [73]. As these tests are often crucial in the clinician's decision about whether the patient has ACO or COPD, it is important to consider them in some detail and to highlight why simple assumptions about how to interpret them can be misleading.

In routine laboratory practice both the measurement of airway hyperresponsiveness (AHR) and BDR rely on changes in the $\mathrm{FEV}_{1}$, the volume that a subject can expire in one second during a forced expiration from total lung capacity. Reliable standards exist for the performance [74] which exploits the development of flow-limitation during the manoeuvre to reduce between test variation. Nonetheless there is a short term and between day physiological variation in the $\mathrm{FEV}_{1}$, which means that tests repeated a few minutes apart can differ by chance by up to $160 \mathrm{~mL}$. Rather surprisingly this between test variability is not much influenced by the initial $\mathrm{FEV}_{1}$ of the subject, although it is somewhat lower when the pre-test $\mathrm{FEV}_{1}$ falls below $1.5 \mathrm{~L}$. By contrast the $\mathrm{FVC}$ is more effort dependent with a potential for more between test variation which has meant that it is less often reported during AHR and BDR tests. This is unfortunate as change in FVC gives more clinically relevant data about lung volume change in COPD and has been suggested as a better guide to AHR in asthma [75].

Although considered as being equivalent measurements of airway smooth muscle responsiveness, AHR and BDR tests are not interchangeable and often say more about the pathology of the surrounding lung than the medium sized airways where most of the inhaled stimulant is delivered. In general, AHR testing is used to diagnose asthma with a series of threshold changes identifying mild to severe degrees of airway irritability. This approach works well if the initial FEV $\mathrm{F}_{1}$ is relatively normal, but as the pre-test $\mathrm{FEV}_{1}$ falls the same dose of agonist can produce a more dramatic fall in $\mathrm{FEV}_{1}$ due to the altered airway geometry rather than a greater degree of airway smooth muscle contraction. In this context, absence of AHR is more informative than its presence, as has been seen when trying to interpret the diagnosis of asthma in obese subjects [34]. Relatively few groups have looked at AHR in more severe COPD. When we did, we found that this was a surprisingly frequent occurrence [76] and accompanied by increases in end-expiratory lung volume, likely reflecting worsening flow limitation with the agonist drug. Although relevant to why such patients were more symptomatic and are prone to more exacerbations of COPD, we were confident that the changes we saw were related to predictable physiological changes in patients with more severe lung damage due to typical smoking-related COPD, as these patients had no pointer to a diagnosis of asthma, either currently or in their past. Structural differences may help explain the observation in mild to moderate COPD that those with the greatest AHR show the fastest decline in $\mathrm{FEV}_{1}$ over time [77].

The situation around interpreting bronchodilator responsiveness is, if anything, even more complex. Table 3 summarises some of the main issues that have emerged over several decades of applying this test in clinical practice. Unlike AHR testing, which examines the ease with which airway smooth muscle contraction can be induced, BDR testing looks at the effect of an inhaled drug that promotes airway smooth muscle relaxation (usually 4 puffs of salbutamol) to improve lung function over a short time, commonly $15 \mathrm{~min}$. This is a satisfying test to conduct in a labile asthmatic patient where the $\mathrm{FEV}_{1}$ can increase by $500 \mathrm{~mL}$ or more and often returns to values within the predicted normal range. This form of acute reversibility is diagnostic of bronchial asthma when it occurs but is not the kind of change commonly seen in patients diagnosed as having ACO. 
Table 3. Problems when interpreting bronchodilator responsiveness in people with COPD [73].

\begin{tabular}{cc}
\hline Pitfall with Reversibility Testing & Reason for the Problem \\
\hline The bronchodilator drug used & $\begin{array}{c}\text { Additional bronchodilation with the } \\
\text { combination of short-acting beta-agonists and } \\
\text { short-acting anti-muscarinics compared to } \\
\text { one bronchodilator }\end{array}$ \\
The timing of reversibility testing & $\begin{array}{c}\text { Short-acting anti-muscarinics achieve } \\
\text { maximum bronchodilation longer than } 15 \text { min } \\
\text { after administration, the timing typically used } \\
\text { for beta-agonist reversibility }\end{array}$ \\
The dose of bronchodilator drug & $\begin{array}{c}\text { Higher doses of salbutamol (>400 mcg) will } \\
\text { result in further small increases in FEV1 } \\
\text { compared with lower doses }\end{array}$ \\
The reproducibility of result & $\begin{array}{c}\text { The magnitude of reversibility, and } \\
\text { classification of reversibility (positive or } \\
\text { negative), varies significantly between tests }\end{array}$ \\
\hline The impact of pre-test FEV1 & $\begin{array}{c}\text { Individuals with a lower pre-test FEV1 are less } \\
\text { likely to shown significant reversibility }\end{array}$ \\
\hline The clinical implications of reversibility & $\begin{array}{c}\text { Reversibility does not predict clinical } \\
\text { symptoms, exacerbations and subsequent } \\
\text { decline in lung function }\end{array}$ \\
\hline
\end{tabular}

As with AHR testing, the physiological basis of BDR is more complex than is commonly appreciated. Airway smooth muscle (ASM) is widely present throughout the bronchial tree down to the terminal bronchioles. In health there is a normal spontaneous variation in the degree of airway smooth muscle activation (ASM tone) which can be reduced or abolished by bronchodilator drugs; hence the enthusiasm of endurance athletes to acquire a diagnosis of asthma. This spontaneous fluctuation in ASM tone is exaggerated in bronchial asthma through a combination of airway inflammation and enhanced ASM bulk [78] but is preserved in COPD. However, in these patients the baseline airway calibre is reduced and structural changes can increase the degree to which normal physiological changes in ASM translate into changes in airflow resistance which is being indirectly assessed by the $\mathrm{FEV}_{1}$. These effects are not as dramatic as is the case in bronchial asthma but are more than enough to account for the variable bronchodilator responses that characterise many COPD patients. None of this requires there to be any 'co-existing' asthmatic pathology in the lungs of the COPD patient.

These theoretical considerations aside, there are many obstacles to the easy interpretation of a bronchodilator reversibility test. The protocol adopted will influence the result. In patients with moderate-very severe airflow obstruction the number of positive tests rises with the number of bronchodilators given to the patient [79], a fact clinically exploited in the use of long-acting inhaled dual bronchodilators [80]. There has been an extensive discussion about how to define a positive result. The simple approach of looking for a large percentage change from baseline works well if the pre-test $\mathrm{FEV}_{1}$ is relatively preserved, but a $160 \mathrm{~mL}$ increase in FEV1 which is within the spontaneous variability of two FEV 1 measurements could be interpreted as $16 \%$ reversibility in a patient with a baseline $\mathrm{FEV}_{1}$ of $1 \mathrm{~L}$. This led to the current recommended volume change which must be at least $12 \%$ of the baseline value and exceed $200 \mathrm{~mL}$ [81]. This was derived from basic principles and experience in population studies rather than empirical data from studies of COPD patients which helps explain its problems in clinical practice. Using a very large absolute difference of $400 \mathrm{~mL}$ between measurements to define a positive test greatly decreases the number of positive responses, but did not abolish the between visit fluctuation in classification in those who tested positive initially as shown in Figure 1 from the ECLIPSE study [82]. 


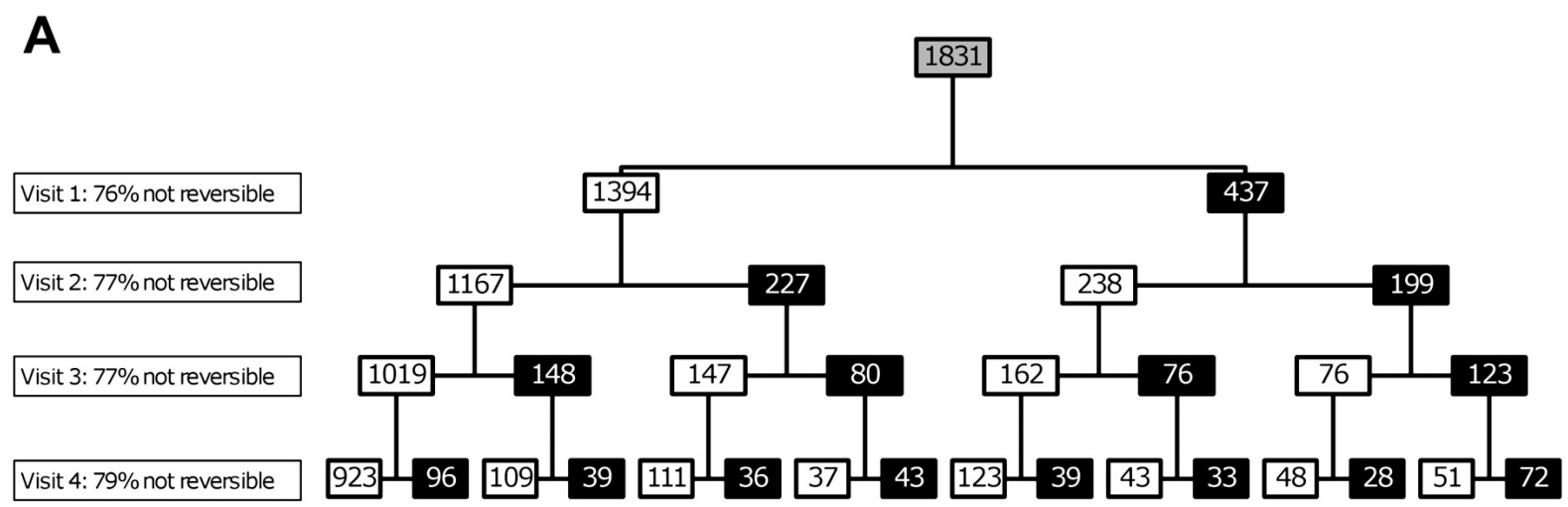

Not reversible Reversible

B
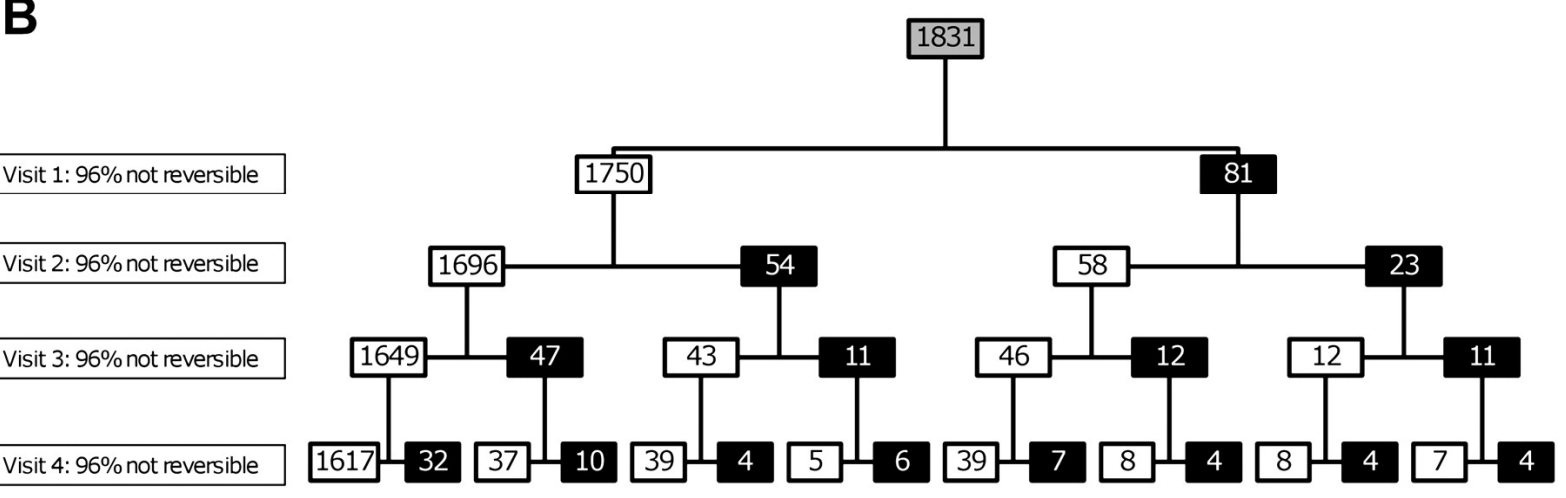

Not reversible Reversible

Figure 1. The reproducibility of the classification of bronchodilator reversibility in 1831 people with COPD who participated in the ECLIPSE cohort study. In (A) reversibility is defined by $\geq 12 \%$ and $\geq 200 \mathrm{~mL}$ increase from pre-bronchodilator $\mathrm{FEV}_{1}$ and (B) an absolute response of $>400 \mathrm{~mL}$ from pre-bronchodilator FEV1 [82].

To use any definition of bronchodilator reversibility to make clinical decisions requires it to be stable from day to day and this is not the case in patients without a history of asthma and diagnosed as having smoking-induced COPD. This became apparent when the reversibility testing data from the ISOLDE study conducted over 20 years ago were analysed [79] and has been confirmed in other large prospective clinical trial populations where carefully standardised reversibility testing was undertaken [82]. Figure 2 illustrates the problem. Over the 3 years of testing, significant numbers of individuals meeting the reversibility criteria at their first visit would be reclassified when tested on a subsequent visit. Overall, the percentage of people in the population testing positive at a given attendance was remarkably constant but the individuals who made up that population varied substantially. These data have to be considered when interpreting the studies described above that have classified individuals as having ACO based on a single bronchodilator test. 


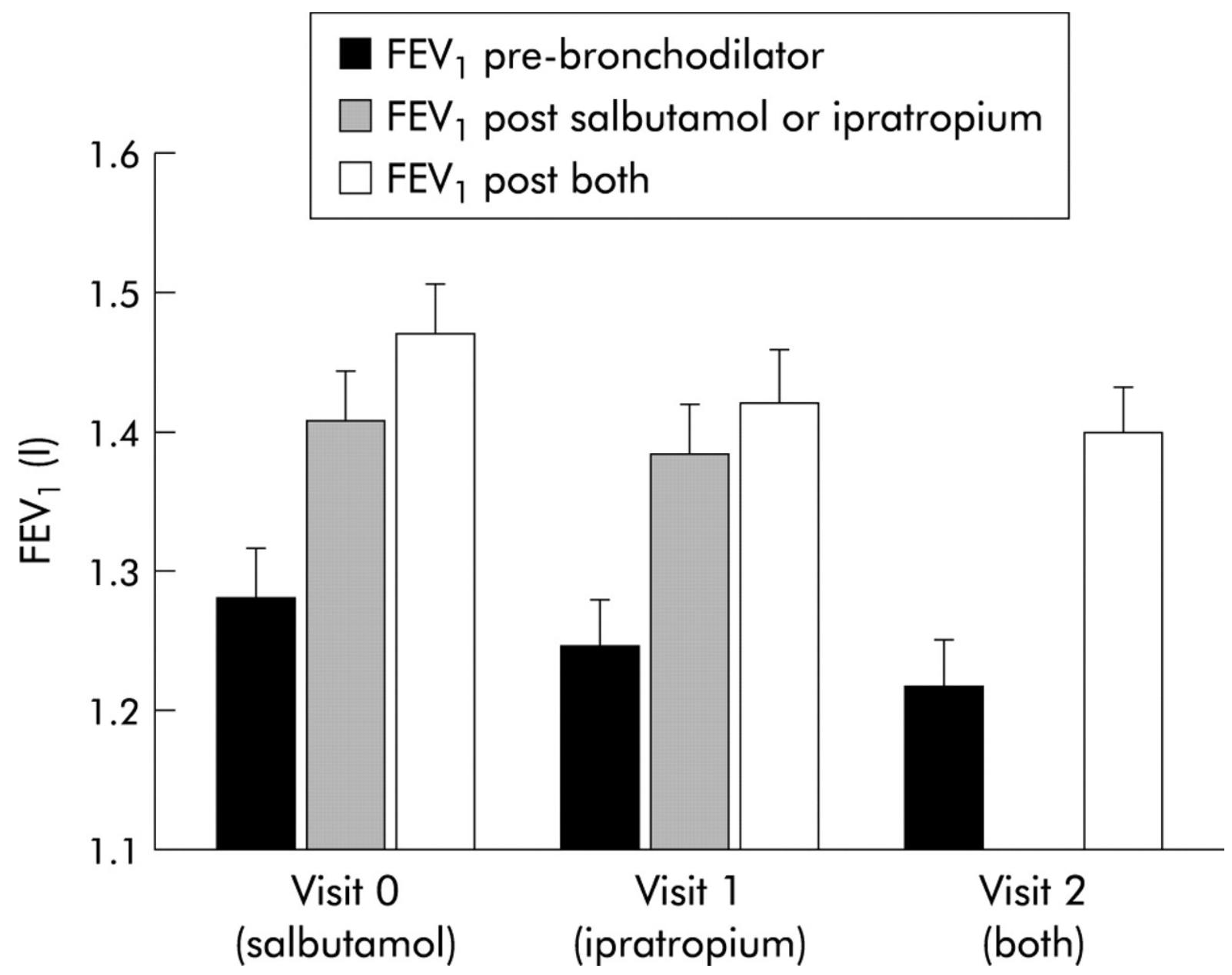

Figure 2. Response to bronchodilators in 660 people with COPD who participated in the ISOLDE study. The results presented show absolute $\mathrm{FEV}_{1}$ pre-bronchodilator and after administration of one or more bronchodilator. At visit 0 subjects received salbutamol followed by ipratropium bromide, at visit 1 ipratropium bromide followed by salbutamol and visit 2 where both bronchodilators were administered together [79].

It would be helpful if patients with a positive BDR on one occasion behaved differently from those who did not but this does not seem to be true, at least in studies where patients did not have a history of prior asthma. The 4-year UPLIFT trial found no relationship between health status or exacerbation rate and the initial bronchodilator response [83]. This was confirmed in the ECLIPSE dataset [82]. The ECLIPSE investigators went on to look at the subset of patients who were consistently positive on testing over 3 years and compared them to those with consistently negative tests and found no difference in mortality, hospitalisation or exacerbation rates.

In summary, classification of individual patients as having an asthma-COPD overlap condition based on a single bronchodilator test is unreliable and influenced by the nature of the test conducted, the severity of pre-test lung function impairment, the way in which it is interpreted and between day fluctuations in ASM tone. How much of the apparent difference in behaviour at a group level is determined by a greater than anticipated improvement in $\mathrm{FEV}_{1}$ after a short-term bronchodilator test remains uncertain.

\section{Therapeutic Implications of ACO}

One of the main reasons to identify patients as having ACO would be to vary their treatment in order to reflect the presence of a presumed dual pathology and potential treatment approaches have been reviewed before [84]. At present there is no evidence base comparing treatment efficacy in individuals meeting any of the ACO definitions with those 
with 'pure' COPD. Indeed, it seems unlikely that important differences would emerge in patients selected on the basis of any of the composite definitions currently proposed. Among COPD patients it is clear that even those who do not exhibit a positive response still benefit from long-acting inhaled bronchodilator treatment in terms of improved exercise capacity and reduced degrees of exertional breathlessness [85]. Hence, it would be illogical to restrict the use of these treatments to those who met the ACO criteria.

The crucial drug class where a clear distinction might be helpful is in the use of antiinflammatory drugs. The most studied class has been ICS and here prior belief seems to trump evidence. For many working in this field it has been an item of faith that inhaled corticosteroids are ineffective in COPD and hence they need an explanation for the large body of data that show that ICS, usually combined with a long-acting inhaled bronchodilator, can improve health status, decrease exacerbation frequency, decrease the rate of decline in $\mathrm{FEV}_{1}$ and prolong life in a large clinical trial population [86]. The suggestion that positive results reflect the presence of a 'hidden' asthmatic population overlapping with 'pure' COPD is not supported by re-analysis of the trial data [87]. However, one characteristic which is part of some definitions of ACO can properly be considered to be a treatable trait on which therapeutic choices about ICS use can be based.

As discussed above blood eosinophil counts have been proposed as a way to identify an ACO subtype of COPD. Airway eosinophilia has been studied in airways disease for almost 20 years mainly focusing on patients with asthma and reporting induced sputum data [88]. However, the relationship between induced sputum eosinophil counts and those in blood is weak in patients diagnosed with COPD [89]. The recognition that COPD patients in the highest tertile of the normal range of eosinophil counts experienced significantly fewer exacerbations when treated with ICS+LABA compared with LABA alone changed perceptions radically [90]. These data were confirmed in other data sets [91,92] as a better understanding emerged about how best to interpret the threshold where the beneficial effect of ICS on exacerbation frequency emerged. In general, this was dictated by the a priori likelihood of an exacerbation occurring and the amount of background bronchodilator treatment, with patients with a blood eosinophil count and a prior exacerbation history being likely to benefit from using ICS irrespective of the degree of concomitant therapy [93]. The extent of peripheral blood eosinophilia did not influence any positive effect of ICS on either $\mathrm{FEV}_{1}$ or health status, but there are retrospective data suggesting that patients with higher blood eosinophil counts have a reduction in lung function loss over time when treated with ICS [94]. Rather surprisingly, the same association between blood eosinophil count and the effect of treatment on exacerbations was seen with a different agent, roflumilast [95]. Like inhaled corticosteroids [96], this drug decreases the degree of eosinophilia seen in airway biopsies [97]. Further mechanistic studies explaining these effects are needed.

The problem for the ACO concept is that the presence of a higher blood eosinophil count is not related to other proposed features of an ACO diagnosis. The distribution of blood eosinophils in COPD populations is not different from that seen in healthy patients without the disease [98], suggesting that the coexistence of a higher count and COPD occurs by chance rather than due to a specific causal mechanism. As noted already, the blood eosinophil count in the large observational NOVELTY study was not different between patients with an ACO diagnosis and those thought to have usual COPD [51], a finding that held true across the clinician-determined range of disease severity (Figure 3). The diagnostic classification did have some significance as ACO patients were more likely to receive ICS treatment in disease perceived to be mild or moderately severe than was the case if COPD alone was diagnosed. However, a similar percentage of patients with severe disease received ICS and ICS+LAMA+LABA treatment irrespective of which diagnostic label was applied. 


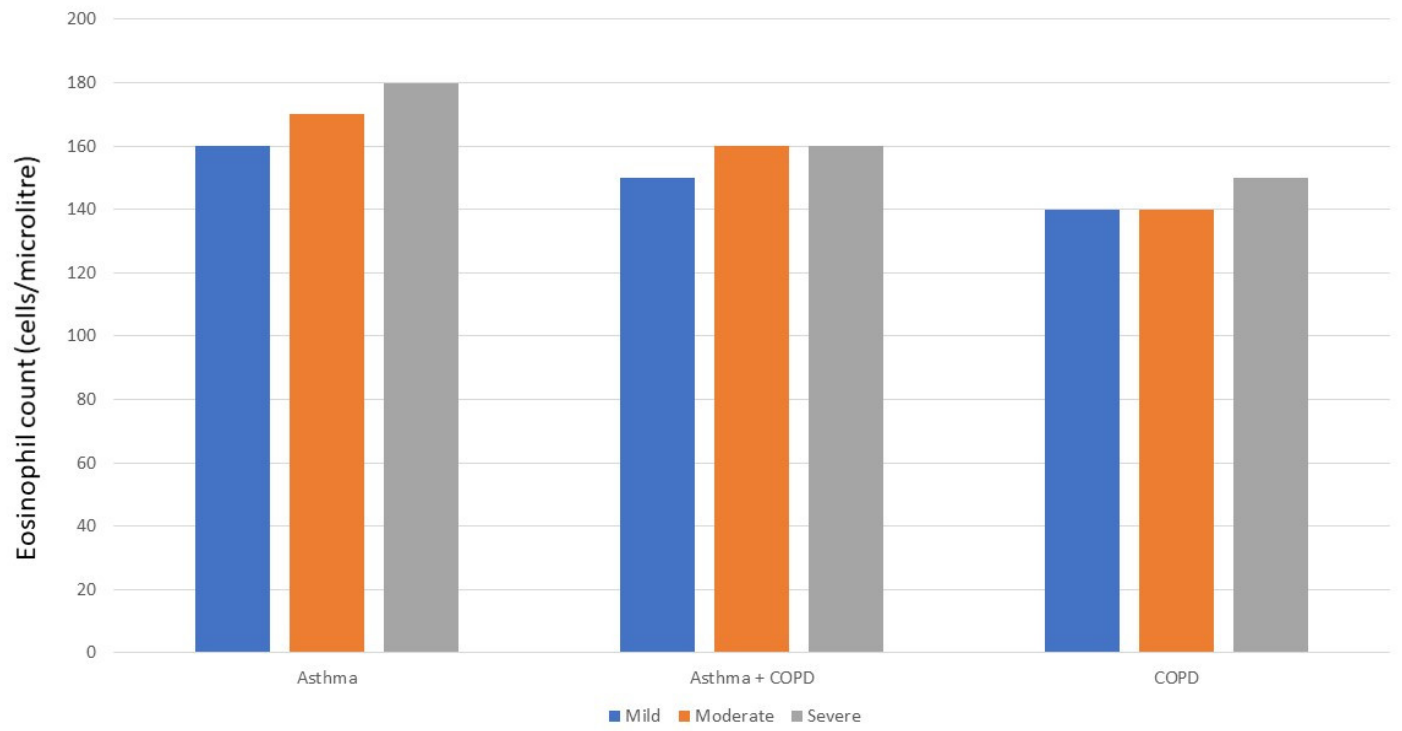

Figure 3. Mean absolute eosinophil count (cells/ $\mu \mathrm{L})$ in 11,243 patients who participated in the NOVELTY study which included 5940 with a physician diagnosis of asthma, 3907 with a physician diagnosis of COPD and 1396 with a physician diagnosis of asthma and COPD. The physician also assessed disease severity as mild, moderate or severe [51].

\section{Conclusions}

Doctors select medical labels for a variety of reasons-to explain to patients that their problems have a rational basis with predictable outcomes that are amenable to proven treatment, to indicate the likely clinical course and prognosis of the condition and finally, on some occasions, to conceal their diagnostic uncertainty and allow them freedom to select treatment that a more restrictive diagnosis would not necessarily allow. It is our view that most cases diagnosed as ACO fall into this last category. This is not due to any ill-intent on the part of the doctor but reflects the multidimensional way in which the diagnosis of asthma and COPD have been presented over the years with a lack of clarity about which features carry most weight in reaching a diagnostic conclusion and uncertainty about how the clinical manifestations of the illness relate to the pathological changes and disease mechanisms which cause them. It is now possible using more objective measurements made in life to categorise these processes differently but the ubiquity of both asthma and COPD, coupled with the long natural history of both conditions, make implementing this a challenging undertaking. Hence, we are likely to be left with composite diagnostic categories which will inform our clinical and academic approach to these conditions. This highlights the need for long-term cohort studies to better understand both the real-life trajectories of COPD and asthma over time, and to better identify phenotypes of patients who may experience features of COPD and asthma. The question remains in this setting-is ACO a useful diagnostic subdivision? As our review of the evidence suggests, we do not believe this is the case.

At the individual patient level, the lack of agreement about what a doctor might mean by the term ACO is a huge drawback. Extrapolating treatment algorithms for this condition based on what occurs in its better-defined progenitor conditions is not helpful. Reliance on a positive bronchodilator response means that the chance of the diagnosis being changed rises with the number of times the test is repeated, even when relatively strict definitions of a positive response are applied. Even if the response is positive, it does not preclude a useful response to the currently available inhaled therapies. Selection of patients based on relative blood eosinophilia has a better evidence base, at least for exacerbation prevention with some anti-inflammatory treatments. However, these beneficial effects are linked to the higher blood eosinophil count (which itself shows modest between day variation) rather than the other features of $\mathrm{ACO}$ and appear to be distributed across the general population rather than confined to a particular subset of patients with airways disease. In 
larger population studies, subjects identified as having ACO report more exacerbations than those with COPD alone. This may reflect the nature of their COPD pathology which increases their apparent AHR and leads to more between day fluctuation in airway calibre for reasons other than abnormal airway smooth muscle function.

Several approaches have been proposed to deal with these issues of classification. In a thoughtful article Wise and Putcha suggest four different 'phenotypes' of ACO (Table 4) which best explain associations between persistent airflow obstruction and asthma [99]. Like the other proposed definitions of ACO, there is a need for longitudinal data to prospectively determine the stability of the diagnostic groups and their subsequent outcomes. A more attractive approach is based on the approach of Agusti et al. who emphasise the treatable traits which may be present in an individual patient, where a high blood eosinophil count is seen as a biomarker of the ability of ICS to prevent exacerbations rather than a defining characteristic of a specific disease [100]. How widely this return to Orie's chronic non-specific lung disease will be accepted remains to be seen. Like others who have reviewed this issue $[17-19,33]$ we tend to the view that it is better to ascribe a dominant likely pathology and describe the individual features that need most attention (e.g., exertional dyspnoea, frequent exacerbations, weight issues, social impacts) rather than creating a separate disease category that follows a different treatment schedule of uncertain relevance to the patient's needs.

Table 4. A suggestion for different pathways to ACO presented as 4 different 'phenotypes' of ACO described by Putcha and Wise [99].

\begin{tabular}{cc}
\hline Phenotype of ACO & Clinical and Biological Features \\
\hline $\begin{array}{c}\text { Smokers with airflow obstruction and } \\
\text { eosinophilic inflammation }\end{array}$ & $\begin{array}{c}\text { Exacerbations driven by eosinophilic inflammation } \\
\text { Better lung function, less emphysema, less } \\
\text { disease progression }\end{array}$ \\
Bester response to oral and inhaled corticosteroids \\
Higher level of atopy
\end{tabular}

Thus, the conclusion reached by the person who has thought most about this topic and advocated the renaissance of the term ACO in 2009, when they revisited this topic in 2015 [62], seems the most appropriate summary of the case against ACO independently of COPD:

"A precise and useful definition of asthma-COPD overlap has not been possible, and the condition itself appears to compromise several different sub-phenotypes. It is proposed that addressing disease components via a multidimensional approach to assessment and management of obstructive airway diseases will be useful to manage the heterogeneity of these conditions."

Author Contributions: P.M.A.C. and P.P.W. conceived, wrote and reviewed this manuscript without additional input or professional writing assistance. All authors have read and agreed to the published version of the manuscript. 
Funding: This research received no external funding.

Institutional Review Board Statement: Not applicable.

Informed Consent Statement: Not applicable.

Data Availability Statement: Not applicable.

Conflicts of Interest: P.M.A.C. has advised many pharmaceutical companies with an interest in COPD including but not restricted to GSK, AstraZeneca, Boehringer Ingelheim, Novartis, Recipharm and Zambon. He has no connections with the tobacco industry. P.P.W. has no conflicts to declare.

\section{References}

1. GBD 2017 Disease and Injury Incidence and Prevalence Collaborators. Global, regional, and national incidence, prevalence, and years lived with disability for 354 diseases and injuries for 195 countries and territories, 1990-2017: A systematic analysis for the Global Burden of Disease Study 2017. Lancet 2018, 392, 1789-1858. [CrossRef]

2. Global Strategy for the Diagnosis, Management and Prevention of COPD; 2021 Report. Available online: https: / goldcopd.org/ wp-content/uploads/2020/11/GOLD-REPORT-2021-v1.1-25Nov20_WMV.pdf (accessed on 12 May 2021).

3. Fletcher, C.; Peto, R. The natural history of chronic airflow obstruction. Br. Med. J. 1977, 1, 1645-1648. [CrossRef] [PubMed]

4. Xu, X.; Dockery, D.W.; Ware, J.H.; Speizer, F.E.; Ferris, B.G. Effects of Cigarette Smoking on Rate of Loss of Pulmonary Function in Adults: A Longitudinal Assessment. Am. Rev. Respir. Dis. 1992, 146, 1345-1348. [CrossRef]

5. Anthonisen, N.R.; Connett, J.E.; Kiley, J.P.; Altose, M.D.; Bailey, W.C.; Buist, A.S.; Conway, W.A.; Enright, P.L.; Kanner, R.E.; O'Hara, P. Effects of smoking intervention and the use of an inhaled anticholinergic bronchodilator on the rate of decline of FEV1. The Lung Health Study. JAMA 1994, 272, 1497-1505. [CrossRef]

6. Burchfiel, C.M.; Marcus, E.B.; Curb, J.D.; Maclean, C.J.; Vollmer, W.M.; Johnson, L.R.; Fong, K.O.; Rodriguez, B.L.; Masaki, K.H.; Buist, A.S. Effects of smoking and smoking cessation on longitudinal decline in pulmonary function. Am. J. Respir. Crit. Care Med. 1995, 151, 1778-1785. [CrossRef]

7. $\quad$ Lange, P.; Celli, B.R.; Agustí, A.; Jensen, G.B.; Divo, M.; Faner, R.; Guerra, S.; Marott, J.L.; Martinez, F.D.; Martinez-Camblor, P.; et al. Lung-Function Trajectories Leading to Chronic Obstructive Pulmonary Disease. N. Engl. J. Med. 2015, 373, 111-122. [CrossRef]

8. Gelb, A.F.; Hogg, J.C.; Müller, N.L.; Schein, M.J.; Kuei, J.; Tashkin, D.P.; Epstein, J.D.; Kollin, J.; Green, R.H.; Zamel, N.; et al. Contribution of Emphysema and Small Airways in COPD. Chest 1996, 109, 353-359. [CrossRef]

9. Drummond, M.B.; Hansel, N.N.; Connett, J.E.; Scanlon, P.D.; Tashkin, N.P.; Wise, R.A. Spirometric Predictors of Lung Function Decline and Mortality in Early Chronic Obstructive Pulmonary Disease. Am. J. Respir. Crit. Care Med. 2012, 185, 1301-1306. [CrossRef] [PubMed]

10. Hardie, J.A.; Buist, A.S.; Vollmer, W.M.; Ellingsen, I.; Bakke, P.S.; Morkve, O. Risk of over-diagnosis of COPD in asymptomatic elderly never-smokers. Eur. Respir. J. 2002, 20, 1117-1122. [CrossRef] [PubMed]

11. Swanney, M.P.; Ruppel, G.; Enright, P.L.; Pedersen, O.F.; Crapo, R.O.; Miller, M.R.; Jensen, R.L.; Falaschetti, E.; Schouten, J.P.; Hankinson, J.L.; et al. Using the lower limit of normal for the FEV1/FVC ratio reduces the misclassification of airway obstruction. Thorax 2008, 63, 1046-1051. [CrossRef]

12. Calverley, P.M.A.; Mueller, A.; Fowler, A.; Metzdorf, N.; Wise, R.A. The Effect of Defining Chronic Obstructive Pulmonary Disease by the Lower Limit of Normal of FEV(1)/FVC Ratio in Tiotropium Safety and Performance in Respimat Participants. Ann. Am. Thorac. Soc. 2018, 15, 200-208. [CrossRef] [PubMed]

13. Bhatt, S.P.; Balte, P.P.; Schwartz, J.E.; Cassano, P.A.; Couper, D.; Jacobs, D.R.; Kalhan, R.; O'Connor, G.T.; Yende, S.; Sanders, J.L.; et al. Discriminative Accuracy of FEV1: FVC Thresholds for COPD-Related Hospitalization and Mortality. JAMA 2019, 321, 2438-2447. [CrossRef]

14. Kerstjens, H.A.; Brand, P.L.; Hughes, M.D.; Robinson, N.J.; Postma, D.S.; Sluiter, H.J.; Bleecker, E.R.; Dekhuijzen, P.R.; De Jong, P.M.; Mengelers, H.J.; et al. A Comparison of Bronchodilator Therapy with or without Inhaled Corticosteroid Therapy for Obstructive Airways Disease. N. Engl. J. Med. 1992, 327, 1413-1419. [CrossRef]

15. Brand, P.L.; Quanjer, P.H.; Postma, D.S.; Kerstjens, H.A.; Koeter, G.H.; Dekhuijzen, P.N.; Sluiter, H.J. Interpretation of bronchodilator response in patients with obstructive airways disease. The Dutch Chronic Non-Specific Lung Disease (CNSLD) Study Group. Thorax 1992, 47, 429-436. [CrossRef] [PubMed]

16. Gibson, P.G.; Simpson, J.L. The overlap syndrome of asthma and COPD: What are its features and how important is it? Thorax 2009, 64, 728-735. [CrossRef] [PubMed]

17. Bateman, E.D.; Reddel, H.; van Zyl-Smit, R.; Agusti, A. The asthma-COPD overlap syndrome: Towards a revised taxonomy of chronic airways diseases? Lancet Respir. Med. 2015, 3, 719-728. [CrossRef]

18. Postma, D.S.; Rabe, K.F. The Asthma-COPD Overlap Syndrome. N. Engl. J. Med. 2015, 373, 1241-1249. [CrossRef]

19. Sin, D.D.; Miravitlles, M.; Mannino, D.M.; Soriano, J.B.; Price, D.; Celli, B.R.; Leung, J.M.; Nakano, Y.; Park, H.Y.; Wark, P.; et al. What is asthma-COPD overlap syndrome? Towards a consensus definition from a round table discussion. Eur. Respir. J. 2016, 48, 664-673. [CrossRef] [PubMed]

20. Ciba Guest Symposium. Terminology, definitions, and classification of chronic pulmonary emphysema and related conditions. Thorax 1959, 14, 286-299. [CrossRef] 
21. Peto, R.; Speizer, F.E.; Cochrane, A.L.; Moore, F.; Fletcher, C.M.; Tinker, C.M.; Higgins, I.T.; Gray, R.G.; Richards, S.M.; Gilliland, J.; et al. The relevance in adults of air-flow obstruction, but not of mucus hypersecretion, to mortality from chronic lung disease. Results from 20 years of prospective observation. Am. Rev. Respir. Dis. 1983, 128, 491-500. [CrossRef]

22. Vestbo, J.; Rasmussen, F.V. Respiratory symptoms and FEV1 as predictors of hospitalization and medication in the following 12 years due to respiratory disease. Eur. Respir. J. 1989, 2, 710-715.

23. Vestbo, J.; Prescott, E.; Lange, P. Association of chronic mucus hypersecretion with FEV1 decline and chronic obstructive pulmonary disease morbidity. Copenhagen City Heart Study Group. Am. J. Respir. Crit. Care Med. 1996, 153, 1530-1535. [CrossRef] [PubMed]

24. Burrows, B.; Niden, A.H.; Fletcher, C.M.; Jones, N.L. Clinical Types of Chronic Obstructive Lung Disease in London and in Chicago. A Study of One Hundred Patients. Am. Rev. Respir. Dis. 1964, 90, 14-27. [CrossRef] [PubMed]

25. Manicatide, M.A.; Teculescu, D.B.; Racoveanu, C.L. Hypoxemia in chronic bronchitis and pulmonary emphysema. Med. Interne 1977, 15, 41-48. [PubMed]

26. Jacques, J.; Cooney, T.P.; Silvers, G.W.; Petty, T.L.; Wright, J.L.; Thurlbeck, W.M. The Lungs and Causes of Death in the Nocturnal Oxygen Therapy Trial. Chest 1984, 86, 230-233. [CrossRef] [PubMed]

27. Orie, N.G.; Slutter, H.J.; Tammeling, G.J. Chronic nonspecific respiratory diseases (Dutch). Ned. Tijdschr. Geneeskd. 1961, 105, 2136-2139.

28. American Thoracic Society. Standards for the diagnosis and care of patients with chronic obstructive pulmonary disease (COPD) and asthma. Am. Rev. Respir. Dis. 1987, 136, 225-244. [CrossRef]

29. Grol, M.H.; Gerritsen, J.; Vonk, J.M.; Schouten, J.P.; Koëter, G.H.; Rijcken, B.; Postma, D.S. Risk Factors for Growth and Decline of Lung Function in Asthmatic Individuals up to Age 42 years. Am. J. Respir. Crit. Care Med. 1999, 160, 1830-1837. [CrossRef]

30. Sears, M.R.; Greene, J.M.; Willan, A.R.; Wiecek, E.M.; Taylor, D.R.; Flannery, E.M.; Cowan, J.O.; Herbison, G.P.; Silva, P.A.; Poulton, R. A Longitudinal, Population-Based, Cohort Study of Childhood Asthma Followed to Adulthood. N. Engl. J. Med. 2003, 349, 1414-1422. [CrossRef]

31. Diagnosis of Diseases of Chronic Airflow Limitation: Asthma, COPD and Asthma-COPD Overlap Syndrome (ACOS). Available online: https://goldcopd.org/wp-content/uploads/2016/04/GOLD_ACOS_2015.pdf (accessed on 13 May 2021).

32. Woodruff, P.G.; Berge, M.V.D.; Boucher, R.C.; Brightling, C.; Burchard, E.G.; Christenson, S.A.; Han, M.K.; Holtzman, M.J.; Kraft, M.; Lynch, D.A.; et al. American Thoracic Society/National Heart, Lung, and Blood Institute Asthma-Chronic Obstructive Pulmonary Disease Overlap Workshop Report. Am. J. Respir. Crit. Care Med. 2017, 196, 375-381. [CrossRef] [PubMed]

33. Cazzola, M.; Rogliani, P. Do we really need asthma-chronic obstructive pulmonary disease overlap syndrome? J. Allergy Clin. Immunol. 2016, 138, 977-983. [CrossRef]

34. Barczyk, A.; Maskey-Warzęchowska, M.; Górska, K.; Barczyk, M.; Kuziemski, K.; Śliwiński, P.; Batura-Gabryel, H.; Mróz, R.; Kania, A.; Obojski, A.; et al. Asthma-COPD Overlap-A Discordance Between Patient Populations Defined by Different Diagnostic Criteria. J. Allergy Clin. Immunol. Pract. 2019, 7, 2326-2336.e5. [CrossRef]

35. Scott, S.; Currie, J.; Albert, P.; Calverley, P.; Wilding, J. Risk of Misdiagnosis, Health-Related Quality of Life, and BMI in Patients Who Are Overweight with Doctor-Diagnosed Asthma. Chest 2012, 141, 616-624. [CrossRef] [PubMed]

36. Brightling, C.E.; Bradding, P.; Symon, F.A.; Holgate, S.T.; Wardlaw, A.J.; Pavord, I.D. Mast-Cell Infiltration of Airway Smooth Muscle in Asthma. N. Engl. J. Med. 2002, 346, 1699-1705. [CrossRef] [PubMed]

37. Perskvist, N.; Edston, E. Differential accumulation of pulmonary and cardiac mast cell-subsets and eosinophils between fatal anaphylaxis and asthma death: A post mortem comparative study. Forensic Sci. Int. 2007, 169, 43-49. [CrossRef]

38. James, A.L.; Bai, T.R.; Mauad, T.; Abramson, M.; Dolhnikoff, M.; McKay, K.O.; Maxwell, P.S.; Elliot, J.G.; Green, F.H. Airway smooth muscle thickness in asthma is related to severity but not duration of asthma. Eur. Respir. J. 2009, 34, 1040-1045. [CrossRef] [PubMed]

39. McDonough, J.; Yuan, R.; Suzuki, M.; Seyednejad, N.; Elliott, W.M.; Sanchez, P.G.; Wright, A.C.; Gefter, W.B.; Litzky, L.; Coxson, H.O.; et al. Small-Airway Obstruction and Emphysema in Chronic Obstructive Pulmonary Disease. N. Engl. J. Med. 2011, 365, 1567-1575. [CrossRef] [PubMed]

40. Koo, H.-K.; Vasilescu, D.M.; Booth, S.; Hsieh, A.; Katsamenis, O.; Fishbane, N.; Elliott, W.M.; Kirby, M.; Lackie, P.; Sinclair, I.; et al. Small airways disease in mild and moderate chronic obstructive pulmonary disease: A cross-sectional study. Lancet Respir. Med. 2018, 6, 591-602. [CrossRef]

41. Hartley, R.A.; Barker, B.L.; Newby, C.; Pakkal, M.; Baldi, S.; Kajekar, R.; Kay, R.; Laurencin, M.; Marshall, R.P.; Sousa, A.R.; et al. Relationship between lung function and quantitative computed tomographic parameters of airway remodeling, air trapping, and emphysema in patients with asthma and chronic obstructive pulmonary disease: A single-center study. J. Allergy Clin. Immunol. 2016, 137, 1413-1422.e12. [CrossRef] [PubMed]

42. Karayama, M.; Inui, N.; Yasui, H.; Kono, M.; Hozumi, H.; Suzuki, Y.; Furuhashi, K.; Hashimoto, D.; Enomoto, N.; Fujisawa, T.; et al. Physiological and morphological differences of airways between COPD and asthma-COPD overlap. Sci. Rep. 2019, 9, 7818. [CrossRef] [PubMed]

43. Papakonstantinou, E.; Savic, S.; Siebeneichler, A.; Strobel, W.; Jones, P.W.; Tamm, M.; Stolz, D. A pilot study to test the feasibility of histological characterisation of asthma-COPD overlap. Eur. Respir. J. 2019, 53, 1801941. [CrossRef]

44. Wenzel, S.E. Asthma phenotypes: The evolution from clinical to molecular approaches. Nat. Med. 2012, 18, 716-725. [CrossRef] 
45. Hastie, A.T.; Martinez, F.J.; Curtis, J.L.; Doerschuk, C.M.; Hansel, N.N.; Christenson, S.; Putcha, N.; Ortega, V.E.; Li, X.; Barr, R.G.; et al. Association of sputum and blood eosinophil concentrations with clinical measures of COPD severity: An analysis of the SPIROMICS cohort. Lancet Respir. Med. 2017, 5, 956-967. [CrossRef]

46. Global Initiative for Asthma. Global Strategy for Asthma Management and Prevention. 2021. Available online: https://ginasthma. org/wp-content/uploads/2021/04/GINA-2021-Main-Report_FINAL_21_04_28-WMS.pdf (accessed on 13 May 2021).

47. Ortega, H.G.; Yancey, S.W.; Mayer, B.; Gunsoy, N.B.; Keene, O.N.; Bleecker, E.R.; Brightling, C.E.; Pavord, I.D. Severe eosinophilic asthma treated with mepolizumab stratified by baseline eosinophil thresholds: A secondary analysis of the DREAM and MENSA studies. Lancet Respir. Med. 2016, 4, 549-556. [CrossRef]

48. Vedel-Krogh, S.; Nielsen, S.F.; Lange, P.; Vestbo, J.; Nordestgaard, B.G. Blood Eosinophils and Exacerbations in Chronic Obstructive Pulmonary Disease. The Copenhagen General Population Study. Am. J. Respir. Crit. Care Med. 2016, 193, 965-974. [CrossRef] [PubMed]

49. Li, M.; Yang, T.; He, R.; Li, A.; Dang, W.; Liu, X.; Chen, M. The Value of Inflammatory Biomarkers in Differentiating Asthma-COPD Overlap from COPD. Int. J. Chronic Obstr. Pulm. Dis. 2020, 15, 3025-3037. [CrossRef] [PubMed]

50. Pérez-De-Llano, L.; On behalf of the CHACOS Study Group; Cosio, B.G. Asthma-COPD overlap is not a homogeneous disorder: Further supporting data. Respir. Res. 2017, 18, 183. [CrossRef]

51. Reddel, H.K.; Vestbo, J.; Agustí, A.; Anderson, G.P.; Bansal, A.T.; Beasley, R.; Bel, E.H.; Janson, C.; Make, B.; Pavord, I.D.; et al. Heterogeneity within and between physician-diagnosed asthma and/or COPD: NOVELTY cohort. Eur. Respir. J. 2021, 25, 2003927. [CrossRef]

52. Christenson, S.A.; Steiling, K.; van den Berge, M.; Hijazi, K.; Hiemstra, P.S.; Postma, D.S.; Lenburg, M.E.; Spira, A.; Woodruff, P.G. Asthma-COPD overlap. Clinical relevance of ge-nomic signatures of type 2 inflammation in chronic obstructive pulmonary disease. Am. J. Respir. Crit. Care Med. 2015, 191, 758-766. [CrossRef]

53. Morgan, B.W.; Grigsby, M.R.; Siddharthan, T.; Chowdhury, M.; Rubinstein, A.; Gutierrez, L.; Irazola, V.; Miranda, J.J.; BernabeOrtiz, A.; Alam, D.; et al. Epidemiology and risk factors of asthma-chronic obstructive pulmonary disease overlap in low- and middle-income countries. J. Allergy Clin. Immunol. 2019, 143, 1598-1606. [CrossRef]

54. Toledo-Pons, N.; van Boven, J.F.M.; Román-Rodríguez, M.; Pérez, N.; Felices, J.L.V.; Soriano, J.B.; Cosío, B.G. ACO: Time to move from the description of different phenotypes to the treatable traits. PLoS ONE 2019, 14, e0210915. [CrossRef] [PubMed]

55. Singh, A.; Liu, C.; Putman, B.; Zeig-Owens, R.; Hall, C.B.; Schwartz, T.; Webber, M.P.; Cohen, H.W.; Berger, K.I.; Nolan, A.; et al. Predictors of Asthma/COPD Overlap in FDNY Firefighters with World Trade Center Dust Exposure: A Longitudinal Study. Chest 2018, 154, 1301-1310. [CrossRef] [PubMed]

56. Cosentino, J.; Zhao, H.; Hardin, M.; Hersh, C.P.; Crapo, J.; Kim, V.; Criner, G.J. Analysis of Asthma-Chronic Obstructive Pulmonary Disease Overlap Syndrome Defined on the Basis of Bronchodilator Response and Degree of Emphysema. Ann. Am. Thorac. Soc. 2016, 13, 1483-1489. [CrossRef] [PubMed]

57. Krishnan, J.A.; Nibber, A.; Chisholm, A.; Price, D.; Bateman, E.D.; Bjermer, L.; van Boven, J.F.M.; Brusselle, G.; Costello, R.W.; Dandurand, R.J.; et al. Prevalence and Characteristics of Asthma-Chronic Obstructive Pulmonary Disease Overlap in Routine Primary Care Practices. Ann. Am. Thorac. Soc. 2019, 16, 1143-1150. [CrossRef]

58. Izbicki, G.; Teo, V.; Liang, J.; Russell, G.M.; Holland, A.E.; Zwar, N.A.; Bonevski, B.; Mahal, A.; Eustace, P.; Paul, E.; et al. Clinical Characteristics of Patients with Asthma COPD Overlap (ACO) In Australian Primary Care. Int. J. Chronic Obstr. Pulm. Dis. 2019, 14, 2745-2752. [CrossRef]

59. Miravitlles, M.; Barrecheguren, M.; Roman-Rodriguez, M. Is a previous diagnosis of asthma a reliable criterion for asthma-COPD overlap syndrome in a patient with COPD? Int. J. Chronic Obstr. Pulm. Dis. 2015, 10, 1745-1752. [CrossRef]

60. Llanos, J.-P.; Ortega, H.; Germain, G.; Duh, M.S.; Lafeuille, M.-H.; Tiggelaar, S.; Bell, C.F.; Hahn, B. Health characteristics of patients with asthma, COPD and asthma-COPD overlap in the NHANES database. Int. J. Chronic Obstr. Pulm. Dis. 2018, 13, 2859-2868. [CrossRef]

61. Baarnes, C.B.; Andersen, Z.J.; Tjønneland, A.; Ulrik, C.S. Determinants of incident asthma-COPD overlap: A prospective study of 55,110 middle-aged adults. Clin. Epidemiol. 2018, 10, 1275-1287. [CrossRef]

62. Gibson, P.G.; McDonald, V.M. Asthma-COPD overlap 2015: Now we are six. Thorax 2015, 70, 683-691. [CrossRef]

63. Nelsen, L.M.; Lee, L.A.; Wu, W.; Lin, X.; Murray, L.; Pascoe, S.J.; Leidy, N.K. Reliability, validity and responsiveness of E-RS: COPD in patients with spirometric asthma-COPD overlap. Respir. Res. 2019, 20, 107. [CrossRef] [PubMed]

64. Pascoe, S.J.; Wu, W.; Collison, K.A.; Nelsen, L.M.; Wurst, K.E.; Lee, L.A. Use of clinical characteristics to predict spirometric classification of obstructive lung disease. Int. J. Chron. Obstruct. Pulmon. Dis. 2018, 13, 889-902. [CrossRef] [PubMed]

65. Bui, D.S.; Burgess, J.A.; Lowe, A.J.; Perret, J.L.; Lodge, C.J.; Bui, M.; Morrison, S.; Thompson, B.R.; Thomas, P.S.; Giles, G.G.; et al. Childhood Lung Function Predicts Adult Chronic Obstructive Pulmonary Disease and Asthma-Chronic Obstructive Pulmonary Disease Overlap Syndrome. Am. J. Respir. Crit. Care Med. 2017, 196, 39-46. [CrossRef] [PubMed]

66. Tai, A.; Tran, H.; Roberts, M.; Clarke, N.; Wilson, J.; Robertson, C.F. The association between childhood asthma and adult chronic obstructive pulmonary disease. Thorax 2014, 69, 805-810. [CrossRef]

67. Tagiyeva, N.; Devereux, G.; Fielding, S.; Turner, S.; Douglas, G. Outcomes of Childhood Asthma and Wheezy Bronchitis. A 50-Year Cohort Study. Am. J. Respir. Crit. Care Med. 2016, 193, 23-30. [CrossRef] 
68. De Marco, R.; Marcon, A.; Rossi, A.; Antó, J.M.; Cerveri, I.; Gislason, T.; Heinrich, J.; Janson, C.; Jarvis, D.; Kuenzli, N.; et al. Asthma, COPD and overlap syndrome: A longitudinal study in young European adults. Eur. Respir. J. 2015, 46, 671-679. [CrossRef] [PubMed]

69. Zheng, X.; Guan, W.; Zheng, J.; Ye, P.; Liu, S.; Zhou, J.; Xiong, Y.; Zhang, Q.; Chen, Q. Smoking influences response to inhaled corticosteroids in patients with asthma: A meta-analysis. Curr. Med. Res. Opin. 2012, 28, 1791-1798. [CrossRef]

70. Sonnex, K.; Alleemudder, H.; Knaggs, R. Impact of smoking status on the efficacy of inhaled corticosteroids in COPD: A systematic review. BMJ Open 2020, 10, e037509. [CrossRef]

71. Gao, J.; Zhou, W.; Chen, B.; Lin, W.; Wu, S.; Wu, F. Sputum cell count: Biomarkers in the differentiation of asthma, COPD and asthma-COPD overlap. Int. J. Chronic Obstr. Pulm. Dis. 2017, 12, 2703-2710. [CrossRef]

72. Brutsche, M.H.; Downs, S.H.; Schindler, C.; Gerbase, M.W.; Schwartz, J.; Frey, M.; Russi, E.W.; Ackermann-Liebrich, U.; Leuenberger, P. Bronchial hyperresponsiveness and the development of asthma and COPD in asymptomatic individuals: SAPALDIA Cohort Study. Thorax 2006, 61, 671-677. [CrossRef] [PubMed]

73. Calverley, P.M.; Albert, P.; Walker, P.P. Bronchodilator reversibility in chronic obstructive pulmonary disease: Use and limita-tions. Lancet Respir. Med. 2013, 1, 564-573. [CrossRef]

74. Miller, M.R.; Hankinson, J.; Brusasco, V.; Burgos, F.; Casaburi, R.; Coates, A.; Crapo, R.; Enright, P.; van der Grinten, C.P.M.; Gustafsson, P.; et al. Standardisation of spirometry. Eur. Respir. J. 2005, 26, 319-338. [CrossRef]

75. Gibbons, W.J.; Sharma, A.; Lougheed, D.; Macklem, P.T. Detection of excessive bronchoconstriction in asthma. Am. J. Respir. Crit. Care Med. 1996, 153, 582-589. [CrossRef]

76. Walker, P.P.; Hadcroft, J.; Costello, R.W.; Calverley, P.M. Lung function changes following methacholine inhalation in COPD. Respir. Med. 2009, 103, 535-541. [CrossRef] [PubMed]

77. Tkacova, R.; Dai, D.L.; Vonk, J.M.; Leung, J.M.; Hiemstra, P.S.; Berge, M.V.D.; Kunz, L.; Hollander, Z.; Tashkin, D.; Wise, R.; et al Airway hyperresponsiveness in chronic obstructive pulmonary disease: A marker of asthma-chronic obstructive pulmonary disease overlap syndrome? J. Allergy Clin. Immunol. 2016, 138, 1571-1579.e10. [CrossRef]

78. Pare, P.D.; Wiggs, B.R.; James, A.; Hogg, J.C.; Bosken, C. The Comparative Mechanics and Morphology of Airways in Asthma and in Chronic Obstructive Pulmonary Disease. Am. Rev. Respir. Dis. 1991, 143, 1189-1193. [CrossRef]

79. Calverley, P.M.A.; Burge, P.S.; Spencer, S.; Anderson, J.A.; Jones, P.W. Bronchodilator reversibility testing in chronic obstructive pulmonary disease. Thorax 2003, 58, 659-664. [CrossRef]

80. Calverley, P.; Vlies, B. A rational approach to single, dual and triple therapy in COPD. Respirology 2016, 21, 581-589. [CrossRef] [PubMed]

81. Pellegrino, R.; Viegi, G.; Brusasco, V.; Crapo, R.O.; Burgos, F.; Casaburi, R.; Coates, A.; van der Grinten, C.P.M.; Gustafsson, P.; Hankinson, J.; et al. Interpretative strategies for lung function tests. Eur. Respir. J. 2005, 26, 948-968. [CrossRef] [PubMed]

82. Albert, P.; Agusti, A.; Edwards, L.; Tal-Singer, R.; Yates, J.; Bakke, P.; Celli, B.R.; Coxson, H.O.; Crim, C.; Lomas, D.A.; et al. Bronchodilator responsiveness as a phenotypic characteristic of established chronic obstructive pulmonary disease. Thorax 2012, 67, 701-708. [CrossRef]

83. Tashkin, D.P.; Celli, B.; Decramer, M.; Liu, D.; Burkhart, D.; Cassino, C.; Kesten, S. Bronchodilator responsiveness in patients with COPD. Eur. Respir. J. 2008, 31, 742-750. [CrossRef]

84. Maselli, D.J.; Hardin, M.; Christenson, S.A.; Hanania, N.A.; Hersh, C.P.; Adams, S.G.; Anzueto, A.; Peters, J.I.; Han, M.K.; Martinez, F.J. Clinical Approach to the Therapy of Asthma-COPD Overlap. Chest 2019, 155, 168-177. [CrossRef]

85. O'Donnell, D.; Voduc, N.; Fitzpatrick, M.; Webb, K. Effect of salmeterol on the ventilatory response to exercise in chronic obstructive pulmonary disease. Eur. Respir. J. 2004, 24, 86-94. [CrossRef]

86. Lipson, D.A.; Barnhart, F.; Brealey, N.; Brooks, J.; Criner, G.J.; Day, N.C.; Dransfield, M.T.; Halpin, D.M.; Han, M.K.; Jones, C.E.; et al. Once-Daily Single-Inhaler Triple versus Dual Therapy in Patients with COPD. N. Engl. J. Med. 2018, 378, 1671-1680. [CrossRef]

87. Han, M.K.; Criner, G.J.; Dransfield, M.T.; Halpin, D.M.G.; Jones, C.E.; Kilbride, S.; Lange, P.; Lettis, S.; Lipson, D.A.; Lomas, D.A.; et al. The Effect of Inhaled Corticosteroid Withdrawal and Baseline Inhaled Treatment on Exacerbations in the IMPACT Study. A Randomized, Double-Blind, Multicenter Clinical Trial. Am. J. Respir. Crit. Care Med. 2020, 202, $1237-1243$. [CrossRef] [PubMed]

88. Green, R.H.; Brightling, C.E.; McKenna, S.; Hargadon, B.; Parker, D.; Bradding, P.; Wardlaw, A.J.; Pavord, I.D. Asthma exacerbations and sputum eosinophil counts: A randomised controlled trial. Lancet 2002, 360, 1715-1721. [CrossRef]

89. Negewo, N.A.; McDonald, V.M.; Baines, K.J.; Wark, P.A.B.; Simpson, J.L.; Jones, P.W.; Gibson, P.G. Peripheral blood eosinophils: A surrogate marker for airway eosinophilia in stable COPD. Int. J. Chronic Obstr. Pulm. Dis. 2016, 11, 1495-1504. [CrossRef] [PubMed]

90. Pascoe, S.; Locantore, N.; Dransfield, M.T.; Barnes, N.C.; Pavord, I.D. Blood eosinophil counts, exacerbations, and response to the addition of inhaled fluticasone furoate to vilanterol in patients with chronic obstructive pulmonary disease: A secondary analysis of data from two parallel randomised controlled trials. Lancet Respir. Med. 2015, 3, 435-442. [CrossRef]

91. Watz, H.; Tetzlaff, K.; Wouters, E.F.M.; Kirsten, A.; Magnussen, H.; Rodriguez-Roisin, R.; Vogelmeier, C.; Fabbri, L.M.; Chanez, P.; Dahl, R.; et al. Blood eosinophil count and exacerbations in severe chronic obstructive pulmonary disease after withdrawal of inhaled corticosteroids: A post-hoc analysis of the WISDOM trial. Lancet Respir. Med. 2016, 4, 390-398. [CrossRef] 
92. Pascoe, S.; Barnes, N.; Brusselle, G.; Compton, C.; Criner, G.J.; Dransfield, M.T.; Halpin, D.M.G.; Han, M.K.; Hartley, B.; Lange, P.; et al. Blood eosinophils and treatment response with triple and dual combination therapy in chronic obstructive pulmonary disease: Analysis of the IMPACT trial. Lancet Respir. Med. 2019, 7, 745-756. [CrossRef]

93. Bafadhel, M.; Peterson, S.; de Blas, M.A.; Calverley, P.M.; Rennard, S.I.; Richter, K.; Fagerås, M. Predictors of exacerbation risk and response to budesonide in patients with chronic obstructive pulmonary disease: A post-hoc analysis of three randomised trials. Lancet Respir. Med. 2018, 6, 117-126. [CrossRef]

94. Barnes, N.C.; Sharma, R.; Lettis, S.; Calverley, P.M. Blood eosinophils as a marker of response to inhaled corticosteroids in COPD. Eur. Respir. J. 2016, 47, 1374-1382. [CrossRef]

95. Martinez, F.J.; Rabe, K.F.; Calverley, P.M.; Fabbri, L.M.; Sethi, S.; Pizzichini, E.; McIvor, A.; Anzueto, A.; Alagappan, V.K.; Siddiqui, S.; et al. Determinants of Response to Roflumilast in Severe Chronic Obstructive Pulmonary Disease. Pooled Analysis of Two Randomized Trials. Am. J. Respir. Crit. Care Med. 2018, 198, 1268-1278. [CrossRef]

96. Pignatti, P.; Visca, D.; Cherubino, F.; Zampogna, E.; Lucini, E.; Saderi, L.; Sotgiu, G.; Spanevello, A. Groningen and Leiden Universities Corticosteroids in Obstructive Lung Disease (GLUCOLD) Study Group. Predictive value of eosinophils and neutrophils on clinical effects of ICS in COPD. Respirology 2018, 23, 1023-1031.

97. Rabe, K.F.; Watz, H.; Baraldo, S.; Pedersen, F.; Biondini, D.; Bagul, N.; Hanauer, G.; Göhring, U.-M.; Purkayastha, D.; Román, J.; et al. Anti-inflammatory effects of roflumilast in chronic obstructive pulmonary disease (ROBERT): A 16-week, randomised, placebo-controlled trial. Lancet Respir. Med. 2018, 6, 827-836. [CrossRef]

98. Landis, S.; Suruki, R.; Maskell, J.; Bonar, K.; Hilton, E.; Compton, C. Demographic and Clinical Characteristics of COPD Patients at Different Blood Eosinophil Levels in the UK Clinical Practice Research Datalink. COPD 2018, 15, 177-184. [CrossRef] [PubMed]

99. Putcha, N.; Wise, R.A. Asthma-Chronic Obstructive Pulmonary Disease Overlap Syndrome: Nothing New Under the Sun. Immunol. Allergy Clin. N. Am. 2016, 36, 515-528. [CrossRef] [PubMed]

100. McDonald, V.M.; Fingleton, J.; Agusti, A.; Hiles, S.A.; Clark, V.L.; Holland, A.E.; Marks, G.B.; Bardin, P.P.; Beasley, R.; Pavord, I.D.; et al. Treatable traits: A new paradigm for 21st century management of chronic airway diseases: Treatable Traits Down Under International Workshop report. Eur. Respir. J. 2019, 53, 1802058. [CrossRef] 